\title{
Modern Study of Philanthropy in Russia: Historical and Legal and Humanitarian Aspects
}

\author{
B.V. Vlasov ${ }^{1}$, A.A. Dabagyan ${ }^{1}$, E.A. Zaitseva ${ }^{1}$, D.G. Ryzhakov ${ }^{1}$, Yu.V. Trofimova ${ }^{1}$ \\ ${ }^{1}$ NSTU named after R.E. Alekseev, Nizhny Novgorod, 603155, Russia \\ *Corresponding author E-mail: vlasov.b.v@mail.ru
}

\begin{abstract}
An attempt to comprehend the main fields of study of various aspects of philanthropy in the Russian Empire at the end of the 19th - early 20th centuries is presented in this article. The aggregate of sources considered on this topic can be conditionally divided into two large groups: the first group - modern domestic publications of both a monographic and a periodic nature; the second group - the Englishlanguage historiography presented by university editions. The article provides an overview of various approaches to the history of philanthropy in the latest specialized scientific journals. The methodology of the article is based on a comparative chronological analysis of numerous publications on the theme of philanthropy in the Russian Empire, as well as the principles of objectivity and historicism.
\end{abstract}

Keywords: Historiography; Philanthropy; Russian empire; Scientific periodicals.

\section{Introduction}

In the domestic and foreign (English-language) historiography, considerable attention has traditionally been paid to the study of various aspects of philanthropy in prerevolutionary Russia. This topic is especially relevant today in connection with the reform of the system for social support and protection of the population. The levels of responsibility of the most important actors in social policy - the state, business, and nonprofit organizations - are reviewed and reallocated. The search for new solutions to the social problems as well as funding sources for social initiatives is of particular importance for society.

A consequence of unrelenting interest is a diverse flow of literature. It is significant that one of the first brief reviews of philanthropy in prerevolutionary Russia is the issue of the pen of the American researcher Madison [1]. The authors hereof believe that three main trends can be distinguished in this study of the history of Russian philanthropy: firstly, the publication of numerous works of educational-methodical and monographic nature $[2,3,4$, $5,6,7,8]$; secondly, holding conferences on topical issues of interest to the authors $[9,10]$; thirdly, an increase in research activity in Russian and foreign periodicals has been observed in the recent decade. The authors will focus their attention not merely on the works of a monographic nature but also on specialized scientific publications, since there are still no general publications reflecting the state of this field of study.

\section{Methods}

To a large extent, the methodology of the work is based on classical general scientific methods: analysis, comparison, and synthesis. Any scientific research in humanitarian (historical and legal) sciences is impossible without the principle of historicism, which involves consideration of the main achievements of science under the influence of the development of public institutions. The fol- lowing methods are used herein: chronological - each element of the study is considered in accordance with the historical stage, the sequence of developments; inductive - based on the analysis of the facts known to the authors, an attempt was made to show the regularities to which the researchers of the Russian philanthropic tradition came.

Following Wilbur K. Jordan, the founder of the study of the history of philanthropy, who made an exceptional contribution to the development of the research methods for the phenomenon of philanthropy [11], the authors will attempt to single out the individual layers of publications reflecting the most important achievements of the researchers of this topic.

\section{Results}

The substantive background in studying the most general issues of the chosen topic was made by already mentioned Madison, whose monograph is concerned with the formation of the social protection system in the Soviet Union [1]. The issues related to the development of philanthropy in imperial Russia are considered in the first part of his study - "Prerevolutionary heritage". Written on the basis of the works of prerevolutionary authors, the chapter is, according to the author, "a brief concentrated analysis of the most important features of the development of Russian philanthropy" [1, pp. 9-23]. An obvious advantage of the work is a detailed analysis of statistical indicators of philanthropy (for example, the indicators of the activity of public assistance departments for 1852, provincial district councils for 1912, the distribution of various types of philanthropy institutions of the Russian Empire are given). Madison examines the evolution of the concept of "social responsibility": from "philanthropy" out of pity, to contractual relations in which society consciously undertakes to support those in need [1, p. 23].

The article by Bradley [12] is written in a different vein. Analyzing the formation and development of the first workhouse in the Russian Empire, opened in Moscow in 1782, the author describes the work and the structure of the institution, the social composi- 
tion of its inhabitants. Statistical calculations, based on archival sources and memoirs, were first introduced into scientific circulation. The comparison of the institution of workhouses in Russia and England is of particular interest. The author points out that the institution of workhouses was created as a method of punishment for vagrancy and begging and was based on repressive measures $[12$, p. 429]. The transformation of these institutions was gradual: they turned from semi-prisonous institutions into the institutions of labor assistance, which occurred after the transfer of workhouses from the state administration to the city in 1892 [13, p. 110]. The book by Ransel [14], Professor the University of Indiana, explores the socio-political prerequisites for the emergence of such type of philanthropy institutions as educational homes during the reign of Catherine II. The work is innovative in that it considers the institution of educational homes through the prism of the value orientations of the autocracy. "In Russia, the educational homes played an even more important role in maintaining faith in the all-powerful monarch and care for the ordinary people from the part of the royal family than family legislation" [14, p. 296], writes Ransel. A wide range of archival and published sources, on the basis of which the scientist described the activities of the educational homes, should be noted.

The collective monograph "Disabled People in the Soviet Union" is focused on various aspects of social protection of persons with disabilities in the Soviet state. The topic of interest for the authors is considered in the first chapter, which is an outline of the relationship between the authorities and people with mental disorders from the 16 th to the early 20 th centuries. The problems of philanthropy are considered in the context of the operation of the provincial district councils [15].

A great contribution to the development of issues of philanthropy was made by Lindenmeyr $[16,17,18]$. By the example of various philanthropy societies and institutions, the author analyzes the policy of autocracy in relation to voluntary philanthropy organizations. The research approach of Lindenmeyr is distinguished by a careful study of sources, including the numerous archival documents of the Ministry of Internal Affairs and the Committee of Ministers. In her conception of philanthropy development in the Russian Empire, Lindenmeyr singled out several periods in the relationship between the state and philanthropy organizations: state regulation of philanthropy in the period before the reforms of $1860 \mathrm{~s}-1870 \mathrm{~s}$; the weakening of strict control in the 1860s; the attempt to modernize the legislation on philanthropy in the $1890 \mathrm{~s}$ For the first time in the English-language literature, the operation of philanthropy associations of national minorities is considered. The researcher convincingly demonstrated the influence of national philanthropy organizations on the self-identification of the peoples of the Russian Empire by the examples of Jewish, Polish and Armenian communities. According to the historian, the activities of national philanthropy unions often masked separatism, which was strengthened under the influence of Russification. Among a wide range of issues developed by Lindenmeyr, a significant place is occupied by the problem of the psychological motives of philanthropy. Having systematized the data of all types of sources, the researcher concludes that the ethical basis of philanthropy in Russia was, first, religious beliefs, second, the fascination with the humanistic ideas among the advanced part of society, and third, the idea of serving the people, popular among the intelligentsia in the postreform period. The totality of the above circumstances and moral attitudes, as well as the adaptation to the Russian terms of the Western principles of "scientifically organized philanthropy" resulted in the flourishing of philanthropy in Russia at the turn of the 19th and 20th centuries [16, p. 680]. The long-term research of Lindenmeyr resulted in her monograph, which is by far the most comprehensive study on this topic [17]. Within the framework of scientific work, the question is raised about the influence of philanthropy organizations on the formation of civil society in prerevolutionary Russia. Considering the features of the emergence of civil society through the activities of philanthropy organizations, Lindenmeyr connects this process with the entrance of the so- called "emancipated" women, formerly dominated, into public life, where the aristocracy used to play the main role. The researcher associates this process with the development of female education and the growth of corresponding organizations that combined philanthropy with mutual assistance [17, pp. 189-194, 18, p. 575]. The articles, somehow related to the topic of interest to the authors, first appeared in the English-language periodicals at the beginning of the 21st century. The development of special literature during this period was marked by the continuation of specific studies in line with the directions and approaches that had been outlined. An interesting perspective in the study, for example, of the legal aspects of philanthropy was proposed by Kaiser, who paid attention to testamentary philanthropy in Russia in the period of the 16th18th centuries [19]. The problems of philanthropic geography were considered by Rabits [20]. The articles by Biryukova on little-known aspects of the philanthropy and educational activities of the Russian Orthodox mission in Korea until 1917 [21], the articles of Fifk on corporate social responsibility [22], the articles of Bobyleva on the support of orphans [23], as well as the articles of Mastromateo on the relationship of social inequality and philanthropy [24], should also be mentioned.

Two periods of study of philanthropy activity - Soviet and postSoviet ones can be distinguished in the domestic historiography. According to some researchers, in the Soviet period, the study of the history of philanthropy was not encouraged because of the predominance of the Marxist ideology, according to which poverty was the result of social relations in the capitalist world and the expression of its contradictions [25]. Philanthropy became an expression of solidarity with a socially close element and acquired a class character. The so-called "public philanthropy", which was directed to the most vulnerable categories of the population, dominated. The Soviet state, which paid great attention to ideology, formed a powerful motivation for philanthropy. The motives of philanthropy were based on the politicization of consciousness, where participation in gratuitous assistance to the needy became one of the social norms. Thus, the philanthropy act turned from a personal action, which it was traditionally, into a public action with a clear class orientation $[25$, p. 139, 26].

The concept of "philanthropy" as an object of research reappeared in the 1990s [27]. The experience of legislative regulation of the activities of philanthropy organizations of imperial Russia [28] was analyzed. The issues of church philanthropy were studied, for example, in the report by Ivanova [29]. The philanthropy of provincial district councils is mentioned in the work by Gerasimenko [30]. The monograph by Bokhanov [31] is concerned with private philanthropy, where philanthropy appears as a typical class feature of the bourgeoisie, and is explained by the preservation of the links among the merchants, industrialists and the people. The work by Aksenov and Dumova considering the philanthropy activity of the largest merchant dynasties in Moscow is of interest [32, 33].

Since the 2000s, as noted above, an unusually large volume of research on specific aspects of regional philanthropy has appeared in the periodicals. The study of local charities allows the use of historical experience in modern social work, as well as identifying the specifics of the economic development of the regions. Thus, various fields of philanthropy in the Tomsk Governorate came to the attention of Sokolova [34] and Seryakova [35]. The first of these authors focused on the study of specific problems of philanthropy in the field of education. The attention was drawn to the high level of interpretation of sources and literature in relation with the study of private and public manifestations of philanthropy in the field of education, as well as the reasoned substantiation of the thesis that since the end of the 19th century, the private initiative in philanthropy had gradually given way to the public one. Sokolova first raised the issue of the relationship between the philanthropy activities and the training of skilled personnel for industrial enterprises. In a similar vein, but at the junction of historiography and source study, an article by Seryakova was written. The purpose of the study was to classify the philanthropy events 
by various parameters on the basis of periodicals, for example, by the degree of popularity among the population. It is noteworthy that philanthropy is seen by the author as a phenomenon of festive urban culture, which is distinguished by the approach of the researcher. The trends of the development of philanthropy in the Russian regions are not ignored. Kryukov [36] dedicated his research to this issue. Analyzing the ways of forming the social partnership based on the materials of the Saratov, Astrakhan and Volgograd Regions, the scientist concludes that it is necessary to create an appropriate regulatory and legal base, which should be aimed at promoting the growth of philanthropy in modern Russia A thorough analysis of the current legislation and historical sources has made it possible to raise the question: "What role is played by philanthropy in the general system of social support for the population?"

Unfortunately, the conclusions are disappointing: philanthropy in Russia is judged as one single aid to the needy, the state is trying to shift all responsibility to public organizations and businesses, and private philanthropy has not yet acquired the role that used to distinguish it in prerevolutionary Russia. It should be noted that the modern bourgeoisie do not need to compensate for the most egregious forms of social damage inflicted on the population, since social support for the population is carried out mainly by the state social security system left from the Soviet Union [36, p. 272]. Special attention has been also paid to such an important topic as the activity of certain categories of philanthropists in the capital regions [37]. Focusing on the activities of the university corporation as participants in philanthropy, Rostovtsev writes that philanthropy was viewed by the professorial community as an important social practice conducive to the creation of civil society. Numerous forms of "educational" philanthropy in the central governorates of the Russian Empire (by the example of the Tula Governorate) came to the attention of Slugina [38]. Based on the archival sources, the researcher identifies the main features of regional philanthropy in the field of education. In particular, the active participation in the philanthropy of "noble class" women is pointed out. The connection between the growth of philanthropy and the possibility to name the scholarships and establishments after the sponsors since 1877, which involved the participants with relatively low social status in the philanthropy [38, p. 364], has been reasonably substantiated. The article by Gerasimova [39], in which this problem is revealed based on the example of a strategically important Ufa Governorate, is of high importance for understanding the mechanism of creation of the institution of guardianship in various regions of the Russian Empire.

The accumulation of factual material, the enhancement and specialization of knowledge on individual elements and stages of the history of philanthropy result in the emergence of new original works. Thus, the importance of philanthropy for the activities of political parties of the first third of the 20th century is considered in the scientific work by Kosterin [40]. The role of the government and the bodies of nobility self-government in the popularization of philanthropy is considered by Pavlichenko [41]. The scientist focuses on introducing into scientific circulation unpublished archival materials, which show how philanthropy contributed to the improvement of market elements in the economy and the welfare of the population.

The specific nature of philanthropy in the Far East is shown in an article by Kotlyar [42]. The starting point of the discussion here is the philanthropy activity of medical and firefighting societies, their interaction with the authorities and local self-government bodies.

The introduction of new sources into the scientific circulation resulted in the extraordinary detailed research and consideration of the local subjects. For example, the greatest attention in the work by Nemashkalov [43] is paid to the administrative and economic details of the activities of the Alexandro-Mariinsky asylums for the poor. The great number of the asylums for the poor in the Russian Empire is explained, according to Nemashkalov, by the ab- sence of other kinds of care (charity) for the poor and the insufficient level of development of the legislation.

Trifonov [44] drew attention to the historical and social features of philanthropy of the church institutions in the Tyumen Governorate in the 19th - early 20th centuries, noting, in particular, the great importance of the church philanthropy activities for the development of the city. A particular attention was paid to the active participation of the priests in teaching, working in hospitals and prisons.

Recently, some aspects of legislative support of philanthropy in the Russian Empire have been studied in details. Thus, the employee of the Tula State Pedagogical University Gavrilina revealed the main directions of the legal regulation of social philanthropy in Russia in the 16th-19th centuries [45]. On the one hand, this was a prohibitive tendency: normative acts aimed at cessation of vagrancy, begging and other forms of behavior, condemned by society, and on the other hand, this was philanthropy, which was to create the conditions for the disabled people to live without violating the law. Wolf studied the extremely important historiographic component of the imperial legislation on philanthropy [46] Considering philanthropy as one of the key elements of public life, Wolf concludes her study with the thesis that not only the legislation contributed to the growth of philanthropy, but mainly the replacement of the hedonistic tendencies of society with new spiritual values.

\section{Conclusion}

Summing up, it should be stated that in modern historiography, despite a number of significant achievements, the study of philanthropy in the Russian Empire remains relevant. The problems related, for example, to the introduction of the legislative heritage of the Russian Empire in the field of philanthropy into modern legal and social practice are still at the periphery of the scientific interest. The differences in the research approaches of Russian and foreign historians should also be noted. Foreign authors are characterized by a more global approach (philanthropy is explored on a nationwide scale, the key issues are the participation of highranking officials in philanthropy, the activities of noble and merchant philanthropy organizations in St. Petersburg and Moscow, the structure and forms of work of the state philanthropy institutions), and by the propensity for generalizations based on analysis of the statistical material. Philanthropy is seen as an integral part of the civil society. Later, this assertion became popular among Russian scientists. Russian-speaking researchers are focused, mainly, on the local aspects of the discussed topic. Numerous publications on the peculiarities of philanthropy in various regions of Russia are written by them.

\section{References}

[1] Madison B (1968), Social Welfare in Soviet Union. Redwood City, California: Stanford University Press.

[2] Lindenmeyr A (1990), Voluntary associations and the Russian autocracy: the case of private charity. Pittsburgh, PA: University of Pittsburgh Center for Russian and East European Studies.

[3] Ulyanova G (1999), The Moscow entrepreneur's charity. Moscow: Moscow State Archive Press.

[4] Xoreva L (1999), History of charity in Russia. S. Petersburg: S. Petersburg University Press.

[5] Kononova T (2005), Essays on the history of charity. Moscow: Dashkov \& K Press.

[6] Kubitsky S (2005), Charity: theory, history, modernity. Chelyabinsk.

[7] Sviridova A (2010), Study of history, trends, charity features as a factor of social support of the population. Tula: Tula polygraphist Press.

[8] Krasnoselcev L (2013), Lectures on the history of charity. Moscow: Moscow University Press. 
[9] Charity: History and rebirth. In Materials of the scientific practical conference 1998. Perm: Perm Regional Museum of Local History Press.

[10] Charity as a form of social responsibility of a business. In the collection of informational and methodical materials of the annual Samara regional conference 2009. Samara: Samara Volunteer Development Center.

[11] Jordan W (1961), The English Background of Modern Philanthropy. American Historical Review 2(66), 401-408

[12] Bradley J (1982), The Moscow Workhouse and Urban Welfare Reform in Russia. Russian Review 4(41), 427-444.

[13] Ulyanova G (1995), The newest American historiography of Russian philanthropy. National history 1, 108-118.

[14] Ransel DL (1988), Mothers of Misery. Child Abandonment in Russia. Princeton, New Jersey: Princeton University Press.

[15] Brown J (1989), Societal Responses to Mental Disorders in Prerevolutionary Russia. In: McCagg WO \& Siegelbaum D, The Disabled in the Soviet Union: Past and Present. Theory and Practice. Pittsburgh, Pennsylvania: University of Pittsburgh Press, 13-39.

[16] Lindenmeyr A (1990), The Ethos in Imperial Russia. Journal of Social History 4(23), 670-694.

[17] Lindenmeyr A (1996), Poverty is not a vice: charity, society, and the state in imperial Russia. Princeton, New Jersey: Princeton University Press.

[18] Lindenmeyr A (1996), Public life, Private Virtues: Women in Russian Charity 1762 - 1914. Signs: Journal of Women in Culture and Society 3(18), 562-591.

[19] Kaiser D (2004), Testamentary Charity in Early Modern Russia: Trends and Motivations. The Journal of Modern History 1(76), 128.

[20] Rabits F (2012), Child sponsorship ordinary ethics and the geographies of charity. Geoforum 2(43), 926-936.

[21] Biryukova V (2014), Russian orthodox mission in Korea until 1917. Pacific Science Review 3(16), 148-155.

[22] Fifka M (2014), An institutional approach to corporate social responsibility in Russia. Journal of Cleaner Production 1(82), 192 201.

[23] Bobyleva T (2015), Development of Social and Educational Support in Russian institutions for Orphans. Procedia - Social and Behavioral Sciences 2(214), 535-543.

[24] Mastromatteo G (2017), Inequality and Charity. World Development 2(96), 136-144.

[25] Vysotsky I (2014), The history of Charity in Russia in theSoviet and post-soviet period. Bulletin of Udmurt University. Series "Historyand Philosophy" 1, 137-145.

[26] Korzhina T (1992), Public organizations of the USSR. Materials for Source Studies and Historiography. Moscow: Russian State Humanitarian University Press.

[27] Badya L (1993), Charity and Philanthropy in Russia: A Brief Historical Essay. Moscow: Moscow Science Publishing House.

[28] Abrosimova E (2002), Historical Aspects of legislative Regulation of the activities of Russian charitable organizations. Proceedings of the 2002 Charity in Russia Scientific Conference, 303-312.

[29] Ivanova N (2001), Charity of the Russian Orthodox Church during World War I. Proceedings of the 2001 History of Russian spirituality Scientific Conference, 26-31.

[30] Gerasimenko G (1990), Zemsvo and self-government in Russia. Moscow Science Publishing House.

[31] Bohanov A (1989), Collectors and Philanthropists in Russia. Moscow Science Publishing House.

[32] Aksenova A (1988), Genealogy of the Moscow merchants. Moscow Science Publishing House.

[33] Dumova N (1992), Moscow philanthropists. Moscow Young Guard Publishing House.

[34] Sokolova L (2000), About Charity in the sphere of primary and secondary professional education in Tomsk province (gubernia) in the second half of the XIXth - beginning of the XXth century. Bulletin of the Tomsk State Pedagogical University, 5(21), 104-108.

[35] Seryakova N (2010), Charity and public leisure of Tomsk citizens in the second half of the XIXth century (based on the materials of the Tomsk Province Gazette). Bulletin of the Tomsk State University $1(9), 55-60$

[36] Kryukov N (2003), Revival of public and private philanthropy in the regions. Journal of Social Policy 1(2), 263-272.

[37] Rostovcev E (2012), Metropolitan Professorship and charity in the early XXth century. Bulletin of Omsk University, 1(3), 106-111.
[38] Slugina N (2012), Pre-revolutionary charity in the field of education and enlightenment in the Tula province. Proceedings of the Tula State University 1(2), 358-367.

[39] Gerasimova D (2013), Guardianship in Ufa province. Theory and practice of social development 10, 273-275.

[40] Kosterin S (2014), From the history of the Warsaw Group of the Constitutional Democratic Party: the transition from political activity to charity. Bulletin of the Russian State Humanitarian University 19, 88-96.

[41] Pavlichenco D (2015), Charitable activity of Voronezh entrepreneurs in the first half of the XIXth century. Scientific notes of Orel State University 3(66), 58-62.

[42] Kotlyar N (2016), From the history of public charity in Far East (late XIXth - early XXth century. Bulletin of the Russian State Humanitarian University 19, 88-96.

[43] Nemashkalov P (2016), Church charity of the Stavropol (Caucasus) eparchy in the late XIXth - early XXth century (By the example of the Alexandro-Mariinsky Diocesan Almshouses). Humanitarian and legal research 3, 97-101.

[44] Trifonov A (2017), Church charity in Tyumen in the XIXth -early XXth century. The Problems of history, philosophy and culture 1, 248-259.

[45] Gavrilina N (2010), Russian legislative regulation of social charity in XVIth - XIXth century. Proceedings of the Tula State University Humanitarian sciences 2, 66-74.

[46] Wolf S (2016), Charitable legislation in the Russian Empire: stumbling block or strong basis for charity development. Bulletin of the Siberian Institute of Business and Information Technology 1(17), 92-100. 